\title{
Prefrontal cortex glutamate afferents are essential for acute and chronic effects of Ritalin
}

\author{
Sheshali Wanchoo ${ }^{*}$, Alan Swann, Nachum Dafny \\ From $1^{\text {st }}$ International Congress on Neurobiology and Clinical Psychopharmacology and European \\ Psychiatric Association Conference on Treatment Guidance \\ Thessaloniki, Greece. 19-22 November 2009
}

\section{Background}

Progressive augmentation of behavioral response following repeated psychostimulant administrations is known as behavioral sensitization, and is an experimental indicator of a drug's liability for abuse (Robinson and Berridge, 1993; Dafny and Yang, 2006). It is known that Ritalin or methylphenidate (MPD), a drug used to treat Attention-Deficit Hyperactivity Disorder (ADHD), induces sensitization in animals following repeated injections [1,2]. Given that many children suffer ADHD, and are treated with MPD, it is essential to know the neuronal circuitry of MPD action. It was recently reported that bilateral electric (non-specific) lesion of PFC prevented behavioral sensitization after chronic MPD administration (Lee et. al., 2008). Since the PFC sends glutamatergic afferents to both ventral tegmental area (VTA) and nucleus accumbens (NAc), sites that are involved in induction and expression of behavioral sensitization to psychostimulants and as PFC glutamatergic afferents are known to modulate the NAc and VTA dopaminergic neurons $[3,4]$, the objective of this study was to study the role of glutamate from PFC in behavioral sensitization to MPD.

\section{Materials and methods}

Locomotor activity of three groups of rats- control, sham operated and group with specific chemical lesion of glutamate neurons of PFC- was recorded using an open-field assay and analyzed. Daily MPD injections were given to all groups on days 9-14 and the animals were rechallenged on the last day after 4 days of washout.

Department of Neurobiology and Anatomy, University of Texas-Houston, Houston, USA

\section{Results}

It was found that the acute and chronic effects of MPD were eliminated in the lesion group.

\section{Conclusions}

Therefore, PFC glutamatergic afferents are essential for the MPD-induced hyperactivity and are also involved in its chronic effects such as behavioral sensitization to multiple MPD administrations.

Published: 22 April 2010

\section{References}

1. Askenasy EP, Taber KH, Yang PB, Dafny N: Methylphenidate (Ritalin): behavioral studies in the rat. Int J Neurosci 2007, 117:757-794.

2. Dafny N, Yang PB: The role of age, genotype, sex, and route of acute and chronic administration of methylphenidate: a review of its locomotor effects. Brain Res Bul 2006, 68:393-405.

3. Kalivas PW, Alesdatter JE: Involvement of NMDA receptor stimulation in the VTA and amygdale in behavioral sensitization to cocaine. J Pharmacol Exp Ther 1993, 267:486-495.

4. Kalivas PW: A role of glutamate transmission in addiction to psychostimulants. Addiction Biology 2000, 5:325-329.

doi:10.1186/1744-859X-9-S1-S88

Cite this article as: Wanchoo et al:: Prefrontal cortex glutamate afferents are essential for acute and chronic effects of Ritalin. Annals of General Psychiatry 2010 9(Suppl 1):S88.

Submit your next manuscript to BioMed Central and take full advantage of:

- Convenient online submission

- Thorough peer review

- No space constraints or color figure charges

- Immediate publication on acceptance

- Inclusion in PubMled, CAS, Scopus and Google Scholar

- Research which is freely available for redistribution 